Scientific Journal of Silesian University of Technology. Series Transport

Zeszyty Naukowe Politechniki Śląskiej. Seria Transport

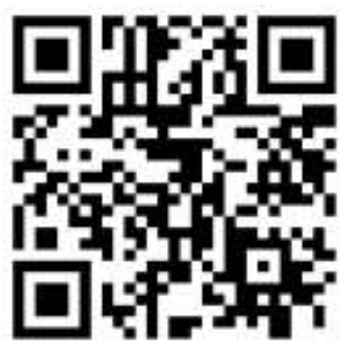

Volume 107

2020

p-ISSN: 0209-3324

e-ISSN: 2450-1549

DOI: https://doi.org/10.20858/sjsutst.2020.107.11

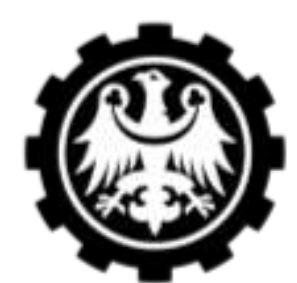

Silesian

University of Technology

Journal homepage: http://sjsutst.polsl.pl

Article citation information:

Rutkowski, M. Forms of insurance of goods transported via water in the inter-uprising period in the Kingdom of Poland. Scientific Journal of Silesian University of Technology.

Series Transport. 2020, 107, 153-163. ISSN: 0209-3324.

DOI: https://doi.org/10.20858/sjsutst.2020.107.11.

Marek RUTKOWSKI ${ }^{1}$

\title{
FORMS OF INSURANCE OF GOODS TRANSPORTED VIA WATER IN THE INTER-UPRISING PERIOD IN THE KINGDOM OF POLAND
}

Summary. In May of 1844, more than twenty years after taking the first steps in the field of regulating watercourse transportation issues, the new law introducing strict water transportation measures in the Kingdom of Poland was accepted by the Russian Tsar. These new proposals, though seen as practically harsh and difficult, for instance, possibly limiting the opportunity of obtaining compensation payments might have given some new strong impulses for the development of Polish water transportations issues as a whole.

Keywords: tsarist transportation, Russian empire, administration structures, 19 th century

\section{REGULATIONS ON THE METHOD OF RECORDING PROTOCOLS REGARDING DAMAGE OF FLOATED GOODS OR PROPERTY ON THE LARGEST WATERCOURSE OF THE KINGDOM OF POLAND - VISTULA RIVER, DATED AS OF 1823}

The relative increase of the Polish state's interest in some kind of protection of the right of owners of items floated via watercourses was decisively required to turn as early as the year 1823. During this time, a relative revival of official interest in the proper protection of items transported in the Kingdom of Poland via river floating was observed.

\footnotetext{
${ }^{1}$ Email: rutmarek@gmail.com
} 
Thus, first as a consequence of an extensive investigation, and as it was reported in the rescript of January 29, 1823, No. 1922/5022, issued by the Tax Department of the Masovian Voivodeship Commission, observation and experience showed that the local police authorities (in this case: mayors of the villages) often in the face of the "breakage" or complete devastation of goods floated on the Vistula river as well as during ".../ other cases involving the destruction or damage of transported commercial facilities" - did not usually and formally follow the procedures adopted by existing regulations.

In practice, these village mayors and other administrative officials did not write in situ the full reports describing investigations done among persons who were involved in accidents as required by the law. This referred primarily to local residents watching the accident, and the participants themselves of the events involved in the rafting. Instead, the mayors only wrote their own comments and observations, which, however, could not be fully taken into account as any evidence of a legal nature.

Obviously, the problem was noticed by the Warsaw's Government Commission of Revenues and Treasury, whose ministry at stake instructed the suitable voivodeship authorities to instruct the local administrative leaders as well as mayors of villages and towns to change the way in which they dealt with diverse accidents, involving freight (goods and properties) floated on the Vistula and other rivers. From then on (strictly speaking from February of 1823), they had to write down their testimonies at the express/immediate request of those concerned. The prepared reports were, of course, to be signed additionally by all possible witnesses of such accidents. Needless saying that only the protocol prepared in this way could be recognised by the local police authorities as correct ${ }^{2}$.

Hence, the first steps towards a correct and useful harmonisation of the regulations confirming the owners' rights to goods damaged or lost during the watercourse voyages could be described in the Kingdom of Poland as appearing in 1823, eight years before the Polish Muscovite war of 1831.

\section{SECURED WATER TRANSPORTATION LAW OF MARCH 19, 1844}

The general issue of insurance turned out to be extremely sensitive in the Kingdom of Poland after the fall of the November Uprising ${ }^{3}$. Particularly, at the beginning of the postuprising Paskievich period, one of the major problems bothering the then state authorities was the idea of paying insurance quotas by the Town and Countryside Fire Association, for fires caused by the war disturbances ${ }^{4}$. The situation was further complicated when pursuant to the decision of the Administrative Council of October 10/22, 1833, the specific and new Insurance Company was founded in the Kingdom to protect the so-called "movables". Originally, the Society was to take care of (apart from everyday movable objects) all types of cereals, both in the grain itself and in sheaves, as well as horses, cattle, sheep and pigs. On the other hand, the care of the new society did not cover gun powder magazines and factories, bills of exchange, or all kinds of public papers (owned by private persons), as well as jewels,

\footnotetext{
2 “Official Journal of Masovian Voivodeship”, No 364, February 17, 1823, p. 10376-10377

${ }^{3}$ On the establishing of insurance institutions in the Kingdom of Poland, see: K. Krzeczkowski, 1931-1935,

Development of public insurance in Poland, vol. 1-2, Warsaw. On the transport insurance issues: ibidem, vol. 2. part. 2 p. 171-174. Among newest publications on the subject one can mention: M. Szczęśniak, 2003, An outline of the history of insurance in Poland, Warsaw; M. Kawiński, 2013, Insurance in the socio-economic development of Poland, in: "Insurance news", Special Number 2/2013, Warsaw , p. 17-18

${ }^{4}$ Central Archives of Historical Record in Warsaw, The Administrative Council of Kingdom of Poland, 1832, signature 24 p. 131-153; „Official Journal of Masovian Voivodeship”, No 15, 2 January 1832, p. 12-13
} 
silver or gold ${ }^{5}$. With all these disturbances and new provisions at stake, the problem of introducing transport insurance, namely, water transported goods, proved to be particularly difficult.

Another ten years passed before the emergence of transport insurances in the post-uprising Kingdom. Specifically, in January of 1843, Tsar Nicholas I issued a decree constituting the foundation for further development of transport insurance company there. This provision clearly indicated the possibility of establishing some insurance procedures in transport (more precisely: in cases dealing with transport losses $)^{6}$.

After Tsar Nicholas I signed a suitable confirmation statement on December 29, 1842 / January 10, 1843, regarding the introduction of the Insurance Act for Water-floated Goods in the Kingdom of Poland, and after presentation of the relevant bill by the Government Committee for Internal, Spiritual and Public Enlightenment Affairs (headed by the Russian Lieutenant general and Senator Alexander Pisariev), the Warsaw's Administrative Council approved the "Act on Securing Floats" at its meeting of March 7/19, 1844. Moreover, the new law was adopted, "recognising the need to establish a Floating Insurance Institution in the Kingdom".

The Administrative Council not only ordered the Government Committee of Internal, Spiritual and Public Enlightenment Affairs to implement the new law but also suggested its further development by the ministry's appropriate staff. So that all interested parties could confidently rely on the new legal solutions in their daily practice, at the same time, the government instructed the Government Committee of Internal Affairs to formally publish its verses in the official Law Digest of the Kingdom of Poland ${ }^{7}$.

As it seemed apparent from the first chapter of the new law (by the way, the new decree was written and published without any preamble, which was not the common custom of the juridical procedures of that time), referring to the remarks of a ruling nature, it was newly established under the name Directorate of Insurances, which had the basic obligation to provide compensation for all losses that could occur while navigating the rivers of the Kingdom: that is, losses of various goods, crops and movables of all types, or categories. Surprisingly, the juridical act at stake even "covered" (although to a small extent) selected areas outside the relevant territory of the Vienna Congress Kingdom of Poland. As such, the new law did not only mention the "Polish" rivers: Nida. Wieprz, Bug, Narew, Pilica, Prosna, Warta, Biebrza and of course the Vistula, as well as the Augustów Canal, but also the entire length of the Niemen River (today: Nemunas) on the distance from the city of Grodno to the Curonian Bay (outside the Kingdom), and even a transport line to the Prussian port of Memel (Klaipeda). In the original text, the insured goods were referred to as via " $/ . . /$ Niemen [Nemunas] up to Memel [Klaipeda] transported", which could and actually mean the transport of goods by the Curonian Lagoon being solely under Prussian sovereignty.

The time period when it was possible (allowed) to normally insure the goods floated via these waters was determined by the Administrative Council for a period stretching from April 1 st of each year and ending on November 1st. In case anyone strongly wanted to secure his rafting proprieties for a longer period extending over November 1st, or beginning before April 1 st of a given year, then one not only had to obtain the special approval of the Directorate of Insurances for this (which depended on supposed "favourable circumstances") but also be

\footnotetext{
5 “Official Journal of Masovian Voivodeship”, No 117, 16 December 1833, p. 1721-1728

${ }^{6} \mathrm{~B}$. Mayzel, Historical review of the development of insurance institutions in the Kingdom of Poland with the addition of a bibliographic image of Polish insurance literature, Warsaw, p. 11-12

7 “Government Gazette of the Kingdom of Poland”, No 83, March 31 / April 12, 1844, p. 527
} 
prepared to pay significant additions for such a privilege. This usually would increase the ordinary sum by $50 \%$ of the amount of the insurance itself, compared to the normal tariff ${ }^{8}$.

In order to facilitate the effective completion of the insurance procedure itself, or any future change to its conditions, the legislator in the article 3rd of the new law of March 19, 1844 , freed all types of correspondence concerning "floating insurances" from typical postal and stamp charges. On the other hand, sending sums of money in cases connected directly or indirectly with the "water transport insurances" was considered possible to be carried out on the same terms as those applicable to the payment of fire insurance receivables (in other words, it was assumed being undertaken in quite the same terms and standards as were used in the correspondence with the Town and Countryside Fire Association).

Pointing to the provenance of the watercourse insurance funds, it was considered discernible that they must first come from generating premium amounts, and perhaps from (other) extraordinary measures. Additionally, it was anticipated that during the first three stages of the effective operation of this type of insurance, the amount of tariff fees was to be determined in accordance with the rates of "those foreign companies that had [previously] accepted insurance of products from the Kingdom, on the Vistula, the Bug and Narew rivers floated". It was only after these first three years that new premiums could be determined in accordance with the financial results achieved by the insurer.

To maintain the financial liquidity of floating insurance, the Administrative Council foresaw the possibility of providing some specific emergency measures. Precisely, in the event of premiums collected (as well as the reserve capital) not being sufficient to cover the current expenses of the water floated goods and proprieties insurer at that time, then the Directorate of (General) Insurances could use in the form of a loan, funds accumulated from other types of insurance activities (for example, mostly from the source of "fire premiums"). The abovementioned amounts had to be repaid in the following years "with the lowest [lending] interest rate [in original: percentage] that these funds bring".

Those "floating insurance funds", which at the time would not be used to cover for current needs, had to be invested in an interest-bearing account at the Bank of Poland, -where, as was in the case of determining the method of sending due financial amounts, the rules for maintaining the financial "water finances surplus" in the main bank of the Kingdom were modelled on the procedures applied to "fire funds"?

Chapter Two of the Act of March 19, 1844, had a significant title: "On the way of joining and accepting float insurances, and on allowing [such] insurances in foreign companies". Here we find out the procedure followed to join the floating/rafting insurance company. It seems that a general rule was adopted; the goods presented for insurance had to be described using Polish markings or weights, as well as weight converters. The above meant that, for instance, after loading transports in Prussia (that is, using local Prussian units of measurement and weights), and crossing the border of the Kingdom, it was necessary to "reduce" these foreign measures on Polish units of account.

A typical person wishing to secure water-floated goods was required to submit in duplicate, a relevant declaration drawn up on specially printed forms. Such a declaration had to include: (a) the family name of the shipowner; (b) the family names of persons employed on the specified ship; c) the name, type and general characteristics of the ship itself; d) optionally the number of "marked" barges; f) designations and quantity of transported items; g) the type and value of goods transported; h) distance of the insured transport route or duration of insurance; i) assessment of the serviceability status and general shape of the

\footnotetext{
8 “Government Gazette of the Kingdom of Poland”, No 83, March 31 / April 12, 1844, p. 527-528

9 “Government Gazette of the Kingdom of Poland”, No 83, March 31 / April 12,1844, p. 528
} 
ship(s) on which the goods were to be carried. The very decision to accept water transported goods for insurance could take place either directly by virtue of the decision of the Directorate of Insurances, or possibly upon the decision of its local commissioners, authorised by the Directorate.

It is only after a thorough analysis of the content of the declaration submitted directly to the offices of the Directorate of Insurances would this agency express its opinion on the amount of money considered as possible (and proposed) for a specific insurance. The management of Directorate of Insurances also decided on the amount of the premium to be paid by the insured person(s). Having made these decisions, only then was a copy of the declaration returned to the applicant by employees of the Directorate of Insurances. The sheer value of items submitted for insurance was calculated based on the invoice analysis of average market prices. Another possible way was to have all insured goods assessed by experts. The prices of goods thus determined were published in an insurance certificate, which meant among others that when making any possible compensation for losses, they could not be reduced under any circumstances.

The goods insurance certificate, constituting as such the very basis for possible future claims, was sent to the person concerned only after meeting some clear financial requirements, specifically after paying the required contribution amount directly at the Ticket Office of the Directorate of Insurances, or after "sending there the determined contribution free of charge" by post.

Nonetheless, should the declaration be submitted to one of its authorised representatives rather than the Warsaw's main office of the Directorate of Insurances, then the whole procedure would seem a bit different. Then, the amount of the sum insured and the premium to be paid on that account was firmly established by the authorised commissioner. After accepting the established financial claim (which also included the costs of sending it, or giving a typically used Latin term - "portoria"), an authorised representative of the Directorate of Insurances issued the insurance certificate to the person concerned, while returning to the applicant one copy of the declaration he had previously submitted to him. It is worthy of note that the insurance certificates were not issued free of charge, for each document of this kind, the insurance administration charged a fee of 15 kopecks.

The Act of March 19, 1844, established the highest amount of money that could be insured in respect of goods carried on one sailing vessel. This sum totally amounted to 9 thousand rubles in silver. Items transported on a barge or on any other sort of "non-sailing ship" could be insured for an amount not exceeding three thousand silver rubles. To generally facilitate money settlements, each insured monetary amount should be in a position where it can be "divided by 10 , without any fraction" 10 .

The period when the insurance of cargo carried via waterways was considered in force, as a general rule, was valid from the moment the premium was paid. However, this did not always apply in an automatic manner because if the goods were insured before they were deposited on the watercraft, then the obligation to pay possible damages arose only when the insured items were loaded onto the ship itself.

The end of validity of a particular insurance contract was established in such a way that exactly at noon on the day marked in the contract was generally considered to be the exact expiring time. Unless the exact date of termination of insurance was described in the contract, the time when the insured items were unloaded on land was considered to be such a moment.

10 “Government Gazette of the Kingdom of Poland”, No 83, March 31 / April 12, 1844, p. 528-529 
At the same time, the maximum length period for keeping goods on board the ship before its final unloading onto the mainland (or another barge) was determined; It is six days after reaching the shore at the latest. In this situation, it became clear that the Directorate of Insurances was not responsible for any damage caused after the unloading of goods or any other insured proprieties. The only exception was when the owner of the goods was able to prove that he could not, for reasons beyond his control, unload his property within the period prescribed by law.

Specifying precisely, the necessary conditions for the solvency of losses occurring while transporting goods via waters, the Administrative Council on March 19, 1844, emphatically pointed out that the responsibility of the Directorate of Insurances was only to consider payments for accidents, the causes of which could only be found in the matter of navigation. The conditions enabling payment of compensation included: a) storms; b) tempests; c) "haemorrhage of water"; d) winds; e) breaking or sinking of the ship; f) hitting the ship against any kind of river hazards; g) the ship overturning when passing through: under bridges, through the gangway, through locks; h) stranding the ship aground.

The Directorate of Insurances was in particular not liable for damages: a) "resulting from transport delay"; b) caused by incorrect distribution of transported goods [both on the deck and beneath it] on the ship carrying goods; c) resulting from inadequate packaging of goods; d) resulting from the transport of items in glass or wooden vessels, especially if the loss occurred as a result of the rupture of the vessels ("or other similar reason"); e) occurring as a result of "spilling" of goods; f) caused by the appearance of rust; g) resulting from partial consumption by mice; $h$ ) occurring as a result of corruption "by the internal disposition of the goods, or by the /.../ influence of air".

Similarly, the insurance administration did not bear any responsibility for damages to property resulting from: a) robbery; b) theft; c) embezzlement by the rowing staff. In addition, the Directorate of Insurances was not entitled to pay for any loss caused by strictly political causes, including: a) confiscation of goods of a prohibited nature (by the tsarist administration), b) "removal by order of [state] authority, or during war" 11.

The law of March 1844 prohibited the insured persons from postponing the date/time of departure, or speeding up departure, the latter was particularly prohibited "in a dangerous time", which meant: a) as regards arriving with the goods before November 1 ; b) in case of departure with goods before April 1 of each year.

Due to a very long delay of the ship (or its stopping) for some unforeseen reasons, including those of atmospheric nature, such as premature appearance of floating ice or pack on rivers, the Directorate of Insurances obtained special rights to dispose of the goods it protected

Particularly, while insurance officials recognised that such a solution would be more appropriate for the proper protection of goods transported by water, officials of the Directorate of Insurances had the right to unload such items at the expense of the insurance company and store them in a safe place. In such an event, the mere guarding of goods and their "further disposition" depended on the owner of the load. In light of the above, it was logical that the Directorate of Insurances was not responsible for damage to the goods after they were unloaded ashore by their employees. More so, protection or even saving of insured goods exposed to danger was rewarded ${ }^{12}$.

\footnotetext{
11 "Government Gazette of the Kingdom of Poland", No 83, March 31 / April 12, 1844, p. 529

12 "Government Gazette of the Kingdom of Poland”, No 84, April 1/ 13, 1844, p. 535
} 
As in the case of other types of insurance, efforts were made to eliminate the competition of foreign insurers (insurance companies) in relation to water transport carried out in the Kingdom of Poland. Hence, Article 23 of the Act of March 19, 1844, described explicitly the idea of prohibiting securing of losses arising from shipping at any foreign insurance companies, especially if such an insurance contract was concluded without prior approval from the Warsaw's insurance company, specifically: Directorate General of Insurances.

The penalty provided for violating this prohibition was five-fold the premium paid in a foreign insurance company. Half of this sum was to fall to a hypothetical "informer" who would have provided the authorities with information about the whole illegal procedure. If, however, it turned out that the owner of items/goods/proprieties illegally insured in a foreign insurance company and simultaneously made their additional insurance in the Polish insurance agency, the possible loss of the last institution was not to be covered in the form of even the smallest compensation.

The Warsaw's Directorate of Insurances had the right to grant special permission to take out insurance "policy" with a foreign company, indicated as capable of granting one. This could only happen if "the value of the given items to be insured exceeded the actual possibilities of its insurance by the Polish state-own company"13.

Part three of the Act of March 19, 1844 was entitled "On proceedings and activities during the insurance period". It started with art. 25 th, where it was pointed out that during a voyage, the owner or skipper (the responsibility of the skipper's actions, moreover, rested on the ship's owner) should apply utmost care to the delivery of the transported goods to their destination as soon as possible, "possibly not interrupted by unnecessary stops".

Based on the fact that some sections of Polish rivers had established specific "retmen" (that is, senior rafters who managed the whole process of rafting), authorised for transporting goods by the Directorate of Insurances, hence, it appeared a rule that only they could transport insured items/property on these specific parts of the watercourses. Correspondingly, the owners of floated units were obliged to follow the principle of professionalism when choosing their rafters and guides, that is, they had to select only highly proficient persons ${ }^{14}$.

The fourth chapter of the law of March 19, 1844, was marked by the title: "On proceedings during damage or sinking of cargo, awarding and payment of remuneration". As it primarily resulted from the provisions given here, after damage/loss of the insured goods/proprieties, their owner should have taken the greatest care with the immediate saving of the rest of the insured items that were not yet significantly damaged. The appropriate remuneration for such action was promised.

There was a need for the insured person or his representative to notify a duly authorised "commissioner" of the Directorate of Insurances as soon as possible about an accident (misfortune). Another possibility was when there was no representative of the insurance company located or be reached nearby, thus, prompt notification of the entire accident to the nearest administrative authority. Such a possibility occurred while taking into account such representatives of administrative staff, as: a) head of a district (poviat); b) the President or mayor of the city; c) the head of a local commune. Simultaneously, altogether with such properly submitted to local authorities a complex report (but while doing so not later than 24 hours after the accident), the insured person had to send a formal notification of the accident directly to the Directorate of Insurances located in Warsaw. In such a report, it was necessary to describe exactly the type of damage suffered, and the monetary value equivalent of the loss.

\footnotetext{
13 "Government Gazette of the Kingdom of Poland", No 83, March 31 / April 12,1844, p 529

14 "Government Gazette of the Kingdom of Poland", No 84, April 1/ 13, 1844, p. 535
} 
Each official to whom the information about an accident was directed was required to go to the scene in person to verify received data about the accident, its circumstances and the individuals involved. It was also his duty to carry out a sort of inquiry among persons who were on the ship at the given moment, or who possibly saw the accident from a short distance.

During the investigation, it was the victim's (that is, person(s) suffering from insured items' loss) party responsibility to prove what specific propriety (and in what quantity and what type) were on the damaged ship/barge. Of course, this concerned only those goods that were designated as insured, and for which compensation was demanded. Such proof could be done by presenting: a) registers; b) contracts concluded with carriers, c) any other written evidence, or d) "in some other way, considered by the delegated representative of the insurance company as sufficiently considered".

After completing the initial stage of the investigation, the loss-affected person should have noted in the report that nothing more than what was written therein was to be added or supplemented. The report was then attached to the "liquidation of damage" protocol, also signed by the victim of the accident, and delegated to the place where the insurance commissioner was to be found. This documentation was subsequently sent at the latest within three days of the event to the local head of the district (poviat).

The most important district official immediately forwards to the Warsaw's Directorate of Insurances, the whole number of files previously submitted to him, including: a) investigation report; and b) "liquidation of losses". To do so, however, there must have been an impassable condition for the existence of demand consisting of a relatively small request of the insurance money amount, not exceeding 150 rubles in silver. Another restriction was the need for the district head of the county to admit the lack of "legitimate reasons to doubt the /.../ reliability" of data presented in the documentation.

Otherwise, or if the damage suffered was greater in value than 150 silver rubles, the duty of the head of the district was to delegate to the place of the accident the local poviat accountant of the Directorate of Insurances, or at least another chosen county official. Their mission was to check what actually happened in situ, and personally carry out the whole investigation concerning loss settlement on site. This way, the district chief submitted to the Directorate of Insurances either only the loss settlement certified by himself or "modernised by himself" the liquidation of losses, for which he had ten days at the latest.

It was not always necessary to follow all the stages of this complicated notification procedure. This could happen when the accident occurred near, or in the vicinity of the capital of the Kingdom. When the "unfortunate event" took place near Warsaw, the victim's only duty was to inform the Directorate of Insurances as soon as possible. This central agenda, in turn, immediately ordered the verification and assessment of the damage by an employee delegated from its capital office.

The next stage of proceedings began with the delivering of "investigation evidence" and "liquidation files" to the offices of the Directorate of Insurances. It was only then that the administrative apparatus of the insurance company could properly proceed with the specific case and possible grant award of remuneration for goods sunk or damaged during navigation.

An extremely important fact was that when the value of goods damaged during shipping turned out to be more than $1 / 4$ of the total insured amount of money, "no more damage, for the same insurance certificate" was covered. The above meant that the owner of the goods floated or in other way transported by a watercourse, could at most expect a refund (calculated from the whole amount of insurance) of $1 / 4$ of the total value of the (lost) goods.

Referring to specific issues, the Act of March 19, 1844, described the procedure to be followed in respect of double-covered or even multiple insured goods. In the event of damage 
to property covered by two or more insurance certificates, the remuneration for each certificate was awarded separately ${ }^{15}$.

There were a number of possibilities where the Directorate of Insurances may refuse to pay compensation. Basically, this could happen if the injured party failed to meet the following conditions. First: a) timely notification of the accident to the Directorate of insurances itself or its authorised local representative within the prescribed period of 24 hours; b) later presentation of any proof of such notification being sent at the post office. Second, such a possibility occurred if during the trip there was (made without properly notifying the Directorate of Insurances) a change in the ship's personnel, or change of barge, responsible for the transport of assured goods. Third, when "unnecessary overloading of the ship caused damage" 16 .

Under certain conditions, the injured party lost the right to receive the assurance amount of money unconditionally. Furthermore, in light of one of the specific reasons (partly described above) for the apparent loss of right for getting insurance payment, the injured individual himself might have become a defendant at the same time, and as such his person might become subject to court proceedings. Such danger threatened especially policyholders of goods transported via watercourses, mostly when they prepared "false" insurance declarations or deliberately concealed in them "something unfavourable to the Directorate of Insurances". Similarly, presenting in the "liquidation application" by the injured party "for unlawful views", a much greater extent of damage than actually took place; as well as a bigger number of damaged or sunken objects led directly to the same results.

Equally dangerous for the victim's party were the possible consequences of actual "hiding" of a number of items and then providing them in the application as lost during the accident. Finally, the insured person lost the right to remuneration and will be threatened with being subjected to court proceedings if it was proved to him that he had contributed intentionally or at the instigation of third parties to damage of secured items, or eventual damage to the ship carrying these goods.

If the "false statement or fraud" made to achieve unauthorised material benefits was found and proved after the payment of the unlawfully granted insurance benefit, and such incorrect payment was discovered and proved after it was actually made, then the Warsaw's Directorate of Insurances reserved itself the right to collect back such amounts of money by way of administrative execution.

With all this, the already properly awarded formal compensation for damaged or sunk during water transport items was to be paid immediately, "and without any deductions". This money could either be collected personally at the Warsaw office of the Directorate of Insurances or after transferring by postal order, at the main offices of the province or district (poviat) governors. The decision on the form and place of receipt of the awarded money belonged directly to the injured person ${ }^{17}$.

\footnotetext{
15 “Government Gazette of the Kingdom of Poland”, No 84, April 1/ 13, 1844, p. 536

16 "Government Gazette of the Kingdom of Poland", No 84, April 1/ 13, 1844, p. 536-537

17 “Government Gazette of the Kingdom of Poland”, No 84, April 1/ 13, 1844, p. 537.
} 


\section{CONCLUSIONS}

The introduction of the Insurance Act for goods/items/proprieties carried by waterways in March 1844 was one of the visual interpretations of the process of consistent pushing out of foreign insurance companies from the Polish insurance market, which was elsewhere exemplified by, for example, regulations in the field of the Fire Association of Towns and Countryside. Noteworthy is the very strict and almost complete definition of the possibilities of actions of the victims to the detriment of the Directorate of Insurances, as well as the clear limitation of the possibility of obtaining compensation payments, equaling only one-quarter of the value of the assured goods. On the one hand, the Act of March 19, 1844, gave Polish watercourse carriers new rights or options in the field of insurance, while effectively eliminating the possibility of choosing an insurer, and limited the amount of compensation of anticipated losses.

\section{References}

1. Archiwum Główne Akt Dawnych w Warszawie. Rada Administracyjna Królestwa Polskiego:1832. Signature: 24. [In Polish: Central Archives of Historical Record in Warsaw. The Administrative Council of Kingdom of Poland].

2. 'Dziennik Urzędowy Województwa Mazowieckiego". February 17, 1823. No 364. Warszawa: Komisja Rządowa Województwa Mazowieckiego. [In Polish: Official Journal of Masovian Voivodeship. Warsaw: Commission of Masovian Voivodeship].

3. "Dziennik Urzędowy Województwa Mazowieckiego". January 2, 1832. No 15. Warszawa: Komisja Rządowa Województwa Mazowieckiego. [In Polish: Official Journal of Masovian Voivodeship. Warsaw: Commission of Masovian Voivodeship].

4. "Dziennik Urzędowy Województwa Mazowieckiego”. December 16, 1833. No 117. Warszawa: Komisja Rządowa Województwa Mazowieckiego. [In Polish: Official Journal of Masovian Voivodeship. Warsaw: Commission of Masovian Voivodeship].

5. "Gazeta Rządowa Królestwa Polskiego". April 12, 1844. No 83. Warszawa: J. Jaworski. [In Polish: Government Gazette of the Kingdom of Poland. Warsaw: J. Jaworski].

6. "Gazeta Rzadowa Królestwa Polskiego". April 13, 1844. No 84. Warszawa: J. Jaworski. [In Polish: Government Gazette of the Kingdom of Poland. Warsaw: J. Jaworski].

7. Kawiński Marcin. 2013. Ubezpieczenia w rozwoju społeczno-gospodarczym Polski. "Wiadomości ubezpieczeniowe". Numer Specjalny 2/2013. Warszawa: Centrum Edukacji Ubezpieczeniowej. [In Polish: Insurance in the socio-economic development of Poland. in: "Insurance news". Special Number 2/2013. Warsaw: Insurance Education Center].

8. Krzeczkowski Konstanty. 1931-1935. Rozwój ubezpieczeń publicznych w Polsce. t. 1-t. 2. Warszawa: Powszechny Zakład Ubezpieczeń Wzajemnych. [In Polish: Development of public insurance in Poland. Vol. 1-2. Warsaw: Universal Mutual Insurance Company].

9. Mayzel Bronisław. 1900. Przeglad historyczny rozwoju instytucyj ubezpieczeń w Królestwie Polskim z dodaniem obrazu bibliograficznego polskiej literatury asekuracyjnej. Warszawa: B. Mayzel. [In Polish: Historical review of the development of insurance institutions in the Kingdom of Poland with the addition of a bibliographic image of Polish insurance literature. Warsaw: B. Mayzel]. 
10. Szczęśniak Marian. 2003. Zarys dziejów ubezpieczeń na ziemiach polskich. Warszawa: Wyższa szkoła Ubezpieczeń i Bankowości w Warszawie. [In Polish: An outline of the history of insurance in Poland. Warsaw: University of Insurance and Banking in Warsaw].

Received 04.03.2020; accepted in revised form 30.04.2020



Scientific Journal of Silesian University of Technology. Series Transport is licensed under a Creative Commons Attribution 4.0 International License 